\title{
White Blood Cell and Serum Biochemistry of Rabbits on Varying Levels of Oyster Mushroom (Pleurotus Ostreatus) Extract under Two Housing Types
}

\author{
Oladipo Olusegun OLATUBOSUN ${ }^{1 *}$, Olajide Mark SOGUNLE ${ }^{1}$, Olajide Andrew ADEYEMI ${ }^{1}$, Adeyemi \\ Mustapha BAMGBOSE², Tolulope Sabainah AREMU ${ }^{1}$ \\ ${ }^{1}$ Department of Animal Production and Health, Federal University of Agriculture, Abeokuta. P.M.B. 2240, \\ Abeokuta, Ogun State, Nigeria. \\ ${ }^{2}$ Department of Animal Nutrition, Federal University of Agriculture, Abeokuta. P.M.B. 2240, Abeokuta, \\ Ogun State, Nigeria. \\ *corresponding author: oladipoolatubosun@yahoo.com
}

Bulletin UASVM Animal Science and Biotechnologies 76(2)/ 2019

Print ISSN 1843-5262; Electronic ISSN 1843-536X

DOI:10.15835/buasvmcn-asb: 0001.19

\begin{abstract}
A total of ninety-six, six weeks old rabbits were grouped into two housing types (steel and wooden hutches), sex (male and female) and four inclusion levels $(0,5,10$ and $15 \mathrm{ml})$ of oyster mushroom extract per litre of water in a $2 \times 2 \times 4$ factorial experimental layout. One rabbit each was selected from each replicate at end of the $10^{\text {th }}$ week of the experiment for white blood cell and serum biochemistry analysis. Results showed that growing rabbits on $5 \mathrm{ml}$ of mushroom (Pleurotus ostreatus) extract per litre of drinking water had the lowest $(\mathrm{P}<0.05)$ neutrophil $(31.00 \%)$ and the highest $(\mathrm{P}<0.05)$ lymphocyte $(67.25 \%)$ in the white blood cell. Male rabbits in steel hutch have a higher $(\mathrm{P}<0.05)$ eosinophil $(0.75 \%)$ in the white blood cell than the female rabbits in steel hutch $(0.00$ \%). Rabbits in steel hutch had a lower $(\mathrm{P}<0.05)$ low density lipoproteins $(13.89 \mathrm{mg} / \mathrm{dl})$ in the serum than rabbits housed in wooden hutch $(16.02 \mathrm{mg} / \mathrm{dl})$. It was concluded that housing rabbits in wooden hutch and inclusion of oyster mushroom up to $15 \mathrm{ml}$ as phytobiotic for rabbits would optimize their health status.
\end{abstract}

Keywords: housing types; steel hutch; wooden hutch; oyster mushroom extract; white blood cell; serum biochemistry; rabbits; phytobiotic.

\section{Introduction}

Housing constitutes an important factor in rabbit production (Mailafia et al., 2010). The main purpose of housing is to protect the rabbits against adverse climatic conditions, predators, ectoparasites and endoparasites (Hoy and Verga, 2006). The main welfare indicators to assess suitability of rabbit housing are mortality, morbidity, physiological parameters, rabbit behaviour and production performance (Hoy,
2008). Steel hutches can be easily cleaned, disinfected and also help to prevent unsanitary conditions and inadequate ventilation, that aid and promote spread of bacterial diseases which wooden hutches are more prone to because wood is very hard to clean and in turn become sources of contamination (Lebas, 1997; Shaeffer and Kime, 2008), however, greater incidence of diseases especially respiratory problems such as pneumonia and chronic respiratory disease 
might be prominent with the use of steel hutches due to uncontrolled air flow. The treatment and control of most of these bacterial diseases is through administration of antibiotic drugs. However, livestock farmers are increasing efforts to eliminate the usage of antibiotics and attempts are been made to replace chemical compounds from conventional multivitamins and antibiotics with natural plant products as active substances to improve on production results, health condition of rabbits and to produce organic rabbit meat (Gugolek et al., 2011). This thus, necessitated the need to search for an organic agriculture friendly and cheaper alternative to the usage of conventional drugs such as the application of mushrooms.

Mushrooms have been widely used as food and food supplements from ancient times. Their usage is being increased day by day for their role as an important food item in human health, nutrition and disease prevention (Chang, 1996; Khan et al., 2008). Dietary mushrooms provide a wide variety of medicinal properties and they are effective against certain life-threatening diseases. These medicinal properties might be due to the presence of some important substance in dietary mushrooms (Alam et al., 2008). Pleurotus species are of highly medicinal importance and values, and this is due to the nutritional and chemical composition of these mushrooms. Pleurotus as health promoter is gaining more importance as compared to other medicinal mushrooms resulting in an upsurge in their research activities during the past decades (Patel et al., 2012). Major medicinal properties attributed to oyster mushrooms include antibiotic, immunity and blood lipid lowering effects (Alam et al., 2008). Pleurotus species of mushroom have some bacteria fighting substances such as pleuromutillin, an antibiotic which can kill various bacteria such as Enterococcus, Escherichia coli, Pseudomonas aeruginosa, Staphylococcus epidermis, Staphylococcus aureus, Streptococcus (Morschhauser et al., 2000; Sandven, 2000; Thomson and Moland, 2000; Stamets, 2005; Nithya and Ragunathan, 2009; Akyuz et al., 2010). Pleurotus species have been reported to possess therapeutic properties like anti-oxidant, anti-inflammatory, immunostimulatory and immunomodulatory (Shamtsyan et al., 2007; Elmastas et al., 2007), and ribonuclease activity (Wang and $\mathrm{Ng}, 2000$ ). P. ostreatus are very effective in reducing the total plasma cholesterol and triglyceride level (Alam et al., 2007) and thus reduce the chance of atherosclerosis and other cardiovascular and artery related disorders. $P$. ostreatus has been explored to combat simple and multiple drug resistant isolates of E. coli, Staphylococcus epidermis, S. aureus (Akyuz et al., 2010) and species of Candida (Wolff et al., 2008), Streptococcus, Enterococcus (Morschhauser et al., 2000; Sandven, 2000; Thomson and Moland, 2000). Hence, this research studied the white blood cell and serum biochemistry of rabbits on varying levels of Oyster mushroom (Pleurotus ostreatus) extract under two housing types.

\section{Materials and Methods}

The experiment was carried out at the Rabbitry Unit of the Directorate of University Farms, Federal University of Agriculture (FUNAAB), Abeokuta, Ogun State, Nigeria. The site is located in the rain forest vegetation zone of South-Western Nigeria on latitude $7^{\circ} 13^{\prime} 49.46^{\prime \prime} \mathrm{N}$, longitude $3^{\circ} 26^{\prime} 11.98^{\prime \prime}$ $\mathrm{E}$ and altitude $76 \mathrm{~m}$ above sea level. The climate is humid with a mean annual rainfall of $1037 \mathrm{~mm}$ and mean temperature range of 31.9 to $34.7{ }^{\circ} \mathrm{C}$ and humidity from 79.7 to $90.1 \%$, respectively.

Ninety-six (96) rabbits consisting of fortyeight (48), six (6) weeks old male rabbits and forty-eight (48) six (6) weeks old female rabbits of mixed breeds (Chincilla, Dutch and New Zealand White) with initial live weight range of 600-650 g were used for the study. The rabbits were allotted on weight equalization basis into two different housing types of steel and wooden hutches of forty-eight (48) rabbits each. The housing types of steel and wooden hutches are further divided into male and female groups of twenty-four (24) rabbits each to check for the effect of sex and each group composed of four (4) varying levels $(0,5$, 10 and $15 \mathrm{ml}$ ) of oyster mushroom (Pleurotus ostreatus) extract per litre of water. Six (6) rabbits were assigned to each treatment group and each group was replicated thrice with two (2) rabbits per replicate. The rabbits were acclimatized for a period of two (2) weeks prior to the start of the experiment. The experiment was carried out for a period of ten (10) weeks. The rabbits were maintained on concentrate diets and a uniform feed composition was fed to the rabbits as shown on Table 1. Antibiotics and multi-vitamins were administered orally in the course of the experiment 
only to rabbits with no level of inclusion of oyster mushroom (Pleurotus ostreatus) extract. The multi-vitamins and antibiotics used was Neotreat WSP $\AA$ from Kepro, Netherlands. The oyster mushroom (Pleurotus ostreatus) extract levels was administered to the rabbits thrice per week and at a day interval within each week. The oyster mushroom (Pleurotus ostreatus) extract levels was administered to the rabbits for eight (8) weeks and withdrawn for the last two (2) weeks of the experiment. The rabbits were housed individually in the steel and wooden hutch with each cell having dimension of $60 \mathrm{~cm} \times 60 \mathrm{~cm} \times 50 \mathrm{~cm}$. Feed and water troughs were provided in the hutches with unrestricted access to feeds and fresh clean drinking water. The rabbits were raised under ambient temperature and photoperiod. Daily routine management procedure was adhered to.

Oyster mushroom (Pleurotus ostreatus) extract was prepared with the use of hot water extraction procedure by extending the boiling process of the mushrooms so as to fully extract the polysaccharides which is considered to be medicinal out of the mushroom cell wall (Sogunle et al., 2016). The Oyster mushroom was poured in the pot at the rate of $500 \mathrm{~g}$ of Oyster mushroom to 1 litre of water and cooked at $57.2^{\circ} \mathrm{C}$ for twenty (20) minutes. The newly formed extracts were then cooled and strain-off the mushrooms with the aid of a sieve. The extracts were kept in a dark-coloured recipient (to prevent photolysis due to light penetration) and then stored in the refrigerator (in the lower compartment of the refrigerator) until needed.

$100 \mathrm{ml}$ of the sample (Oyster mushroom extract) was mixed with $50 \mathrm{ml}$ absolute methanol by soaking in a well cleaned bottle for a week. The mixture was shaken vigorously and allowed to stand in order to form a suspension. The organic solvent with extract was collected by filtering into a quartz beaker, the process was repeatedly carried out for two more consecutive times. The aliquot collected were combined and concentrated on a steam bath to about $5 \mathrm{ml}$. This was purified by passing through a pasture pipette packed with anhydrous sodium sulphate on a membrane and air dried to about 2 $\mathrm{ml}$ for gas chromatographic analysis. The extract of the sample was subjected to Gas Chromatographic and Mass Spectroscopy (GC/MS) analysis, this group of powerful instruments interfaced helped to characterize the various compositions. The gas chromatographic Model: 7890A (GC) analysis was performed on an Agilent Technologies interfaced with Mass Selective Detector model: 5975C (MSD). The electron ionization was at a $70 \mathrm{v}$ with an ion source temperature at $250{ }^{\circ} \mathrm{C}$. Highly pure helium gas ( $99.9 \%$ purity) was used as carrier gas, while HP-5ms (30 mm X 0.25 mm X $0.320 \mu \mathrm{m}$ ) was used as the stationary phase. The oven temperature was at $80{ }^{\circ} \mathrm{C}$ held for 5 minutes and increased to $250{ }^{\circ} \mathrm{C}$ while holding for 16 minute at the rate of 4 degrees/minute $1 \mu$ / l was auto injected.

One (1) rabbit each was selected from each replicate at end of the $10^{\text {th }}$ week of the experiment for white blood cell and serum biochemistry analysis. Blood sample of $3 \mathrm{ml}$ of blood was withdrawn from the ear vein of each rabbit by means of sterile hypodermic needle and syringe in the morning between 7:00 and 9:00. About 0.5 $\mathrm{ml}$ was used for white blood cell differential and stored in Bijou bottles with ethylene diamine tetra acetate (EDTA) as anticoagulant while the other $2.5 \mathrm{ml}$ was stored without coagulant for serum biochemistry analysis. Sample bottles containing blood samples were placed on ice packs to maintain a cool and stable temperature and immediately sent for laboratory analysis.

The estimate of the total number of white blood cells was carried out immediately after collection of blood sample from the rabbits using Neubauer haemocytometer counting chamber (Jain, 1986). About $0.2 \mathrm{ml}$ of blood sample was pipetted and mixed with $4 \mathrm{ml}$ of WBC diluting fluid (WBC fluid made up of $3 \%$ aqueous solution of acetic acid and $1 \%$ gentian violet). The sample was then put into the haemocytometer and cell counted and expressed as $10^{9} \mathrm{WBC}$ per litre of blood. The values for neutrophils, lymphocytes, monocytes, eosinophils and basophils were determined from the white blood cell count.

The serum biochemical measurements determined are total serum protein, serum globulin, serum albumin, serum glucose, serum urea, serum creatinine, serum cholesterol, high density lipoprotein (HDL), low density lipoprotein (LDL), and triglycerides.

Total serum protein was prepared according to Kaneko (1989) using two solution. The first solution consists of $45 \mathrm{~g}$ of sodium potassium tetrates (Rochelle salt) dissolved in $400 \mathrm{ml}$ of $0.2 \mathrm{~N}$ $\mathrm{NaOH}$ in a beaker. $1.5 \mathrm{~g}$ of $\mathrm{CuSO}_{4} .5 \mathrm{H}_{2} \mathrm{O}$ and $5 \mathrm{~g}$ of potassium iodide was added and was dissolved 
completely by stirring. The mixture was rinsed with $0.2 \mathrm{~N} \mathrm{NaOH}$ and poured into a flask. The solution was made up to a litre with $0.2 \mathrm{~N} \mathrm{NaOH}$. The second solution consists of $0.5 \%$ potassium iodide (Kl) in $0.2 \mathrm{~N} \mathrm{NaOH}$ working Biuret reagent. An aliquot of first solution was diluted to $250 \mathrm{ml}$ with second solution. An aliquot of $0.1 \mathrm{ml}$ was pipetted into a test tube and $2.9 \mathrm{ml}$ of water was added. The blank consisting of $3.0 \mathrm{ml}$ distilled water was pipetted into the test tube. To each test tube, $3.0 \mathrm{ml}$ of working biuret reagent was added and all the tubes were incubated in $37^{\circ} \mathrm{C}$ water bath for 10 minutes. Readings were taken at 540 $\mathrm{nm}$ after setting the instruments to zero with the blank solution. Total serum protein of each sample was calculated from the formula below:

Total Serum Protein $(\mathrm{g} / 100 \mathrm{ml})=$

Optical density of test $\times$ Concentration of standard Optical density of standard

Serum albumin was determined using the bromocresol purple method. The bromocresol purple is a stable complex with absorbance maximum at $600 \mathrm{~nm}$. The intensity of the colour produced is directly proportional to the albumin concentration of the sample. $4 \mathrm{ml}$ of bromocresol purple was added to $0.2 \mathrm{ml}$ of each of the serum samples. Bromocresol purple solution $(4 \mathrm{ml})$ was used as a blank. The content of each tube was mixed and left at room temperature for 10 minutes at pH $4.2 \pm 0.05$. After 10 minutes, the test solution was read at a wavelength of $640 \mathrm{~nm}$ in a spectrophotometer set to zero with the blank solution. Values of the samples were calculated using the formula:

Serum albumin $(\mathrm{g} / 100 \mathrm{ml})=$

Optical density of test $\times$ Concentration of standard Optical density of standard

Serum globulin was calculated as follows:

Serum globulin $(\mathrm{g})=$

Total Serum Protein (g) - Serum albumin (g)

Serum urea was determined using a kit (Quinica clinical spam) having a linear measurement of about $566.6 \mathrm{ml}$ per litre of urea concentration. The serum urea was determined calorimetrically. The spectrophotometer (Model SP6-400 Ur Pyeunicam) was set at $600 \mathrm{~nm}$ wavelength and equivalent wavelength of sample read. Serum urea was calculated as:

Urea $(\mathrm{mg})=$

Sample Optical Density $\times 40$

Optical density of standard
Serum creatinine was analysed using calorimetric method. $1.0 \mathrm{ml}$ of trichloroacetic acid and $1.0 \mathrm{ml}$ of serum was mixed and centrifuged at $250 \mathrm{rpm}$ for 10 minutes and the supernatant poured off. The mixture was allowed to cool for 20 minutes at a temperature of $25^{\circ} \mathrm{C}$. The absorbance of the sample and standard was measured against the blank.

Concentration of Creatinine $(\mathrm{mg} / \mathrm{dL})=$ Absorbance of sample $\times 2$

Absorbance of standard

The serum cholesterol was determined using enzymatic endpoint method as described by Roeschlau et al. (1974). The reading taken at wavelength $520 \mathrm{~nm}$.

High density lipoproteins (HDL) was determined as follows. About $200 \mu \mathrm{l}$ of test sample was precipitated and left for 10 minutes. The supernatant was centrifuged at $4000 \mathrm{rpm}$ for 10 minutes. Sample supernatant of $100 \mu \mathrm{l}$ was added to $1000 \mu \mathrm{l}$ cholesterol reagent, mixed well and incubated for 10 minutes at $37^{\circ} \mathrm{C}$. The absorbance was read against blank on a spectrophotometer at 505 nm (Randox, 2012).

Concentration of HDL $(\mathrm{mg} / \mathrm{dL})=$ Absorbance of test $\times$ Concentration of standard Absorbance of standard

Low density lipoproteins (LDL) was determined as follows:

About $10 \mu \mathrm{l}$ of sample test was mixed well with $1000 \mu \mathrm{l}$ of LDL cholesterol reagent and incubate for 10 minutes at $37^{\circ} \mathrm{C}$ with the standard. It absorbance was read against blank on a spectrophotometer at $505 \mathrm{~nm}$ (Randox, 2012).

Concentration of LDL $(\mathrm{mg} / \mathrm{dL})=$

Absorbance of test $\times$ Concentration of standard

Absorbance of standard

Serum triglyceride was analysed using a spectrophotometer by measuring the absorbance of alkali hydrolysis forming glycerol which is oxidised to form periodate of test sample after incubation for 10 minutes at $37^{\circ} \mathrm{C}$ and read against the blank at $505 \mathrm{~nm}$ and standard reagents (Randox, 2012).

Concentration of triglyceride $(\mathrm{mg} / \mathrm{dL})=$ Absorbance of test $\times$ Concentration of standard Absorbance of standard

The experiment layout was a $2 \times 2 \times 4$ factorial arrangement and the data generated were subjected to a Completely Randomized Design. The rabbits were grouped into two housing types 
Table 1: Gross composition of concentrate diet for the rabbits

\begin{tabular}{cc}
\hline Ingredients & Composition (\%) \\
\hline Maize (Yellow) & 35.00 \\
\hline Soya bean meal & 10.00 \\
\hline Wheat offal & 20.00 \\
\hline Rice bran & 17.00 \\
\hline Palm kernel cake & 12.00 \\
\hline Fish meal (65\%) & 2.00 \\
\hline Bone meal & 2.00 \\
\hline Limestone & 1.00 \\
\hline Premix (Growers) & 0.50 \\
\hline Salt (NaCl) & 0.50 \\
\hline Total & 100.00 \\
\hline Calculated Analysis & 10.53 \\
\hline ME (MJ/kg) & 16.64 \\
\hline Crude protein (\%) & 6.68 \\
\hline Crude fibre (\%) & 5.99 \\
\hline Ether extract (\%) &
\end{tabular}

(steel and wooden hutch), sex (male and female) and of four inclusion levels $(0 \mathrm{ml}, 5 \mathrm{ml}, 10 \mathrm{ml}$ and $15 \mathrm{ml}$ ) of Oyster mushroom (Pleurotus ostreatus) extract per litre of drinking water. Significantly $(\mathrm{P}<0.05)$ different means were separated using Tukey Test as contained in Minitab ${ }^{\circledR}$ 17.1.0 (2013). The data generated were analysed with the use of General Linear Model (GML) of the same package.

\section{Results and Discussion}

The results of the phytochemicals of Oyster mushroom (Pleurotus ostreatus) extract are presented in Table 2. The results are classified into the active compounds, quality, percentage composition of each compound and their bioactivity. The active compounds of 9-Octadecenoic acid (Z), methyl ester (oleic acid); Methyl octadeca-10, 13-dienoate; and 9, 12-Octadecadienoic acid $(\mathrm{Z}, \mathrm{Z})$, methyl ester (linoleic acid) in the Oyster mushroom (Pleurotus ostreatus) are of the highest quality while the least of quality was 1,6-Octadiene, 3, 7-dimethyl-, (S)- (linalool). The most abundant of these compounds was 9,12-Octadecadienoic acid (Z,Z)- methyl ester which is linoleic acid; a polyunsaturated fatty acid with a constituent of $30.10 \%$ while the least compounds contained in Oyster mushroom extract were 2H-Pyran, 3, 4-dihydro and Methyl 20-methyl-heneicosanoate with $1.94 \%$, respectively. The phytochemical analysis of Oyster mushroom extract in this study disclosed the presence of phyto-constituents. The presence of Benzene acetaldehyde; a flavonoid compound which has antimicrobial properties was observed. The odor from Pleurotus mushroom called Anise could be attributed to the presence of benzaldehyde which smells more like almonds. Eman Mostafa and Farghaly (2014) observed the presence of benzene, 1-chloro-4methoxy- ( 0.8 mass fractions) and benzene acetic acid (0.3 mass fractions) in Oyster mushroom with Benzene acetic acid being an active plant hormone, possessing a honey-like odor in low concentrations. The presence of Hexadecanoic acid, methyl (methyl palmitate) which also has antimicrobial and antioxidant properties was observed. This supports Wasser (2002) and Elmastas et al. (2007) who reported the presence of antioxidant activity and antioxidant compounds in edible Oyster mushrooms.

Table 3 shows the effects of housing types, sex and inclusion levels of Oyster mushroom on white blood cell count and white blood cell differential of rabbits. The housing types and the sex did not significantly $(\mathrm{P}>0.05)$ influence white blood cell, neutrophil, lymphocyte, eosinophil, basophil and monocyte of the rabbits. However, the inclusion levels of Oyster mushroom had significant $(\mathrm{P}<$ 0.05 ) differences on neutrophil, lymphocyte of the rabbits. The rabbits on $0 \mathrm{ml}$ (antibiotics and multivitamins) had the highest neutrophil (36.13 $\%$ ) from the white blood cell while the rabbits on $5 \mathrm{ml}$ of mushroom extract in drinking water had the lowest $(31.00 \%)$. The rabbits on $5 \mathrm{ml}$ of mushroom extract in drinking water had the 
Table 2: Phytochemicals of Oyster mushroom (Pleurotus ostreatus) extract

\begin{tabular}{|c|c|c|c|c|}
\hline Active Compounds & Quality & Percentage & Bioactivity & References \\
\hline 2H-Pyran, 3, 4-dihydro- & 53 & $1.94 \%$ & $\begin{array}{c}\text { Install tetrahydropyranyl (THP) } \\
\text { protecting groups on alcohol and } \\
\text { amines }\end{array}$ & $\begin{array}{l}\text { Eman Mostafa and Farghaly, } \\
\text { 2014; Jadhav et al., } 2014\end{array}$ \\
\hline Benzene acetaldehyde & 90 & $2.76 \%$ & Antimicrobial & $\begin{array}{c}\text { Jadhav et al., 2014; Joseph and } \\
\text { Priya, 2011; Patel et al., 2012; } \\
\text { Golak-Siwulska et al., } 2018 \\
\end{array}$ \\
\hline 2-Pyrrolidinone & 80 & $5.02 \%$ & $\begin{array}{l}\text { e.g. Doxapram - stimulates } \\
\text { chemoreceptors in the carotid } \\
\text { arteries which in turn, stimulates the } \\
\text { respiratory centre in the brain stem. }\end{array}$ & $\begin{array}{l}\text { Eman Mostafa and Farghaly, } \\
\text { 2014; Golak-Siwulska et al., } \\
2018\end{array}$ \\
\hline Methenamine & 91 & $8.14 \%$ & $\begin{array}{l}\text { Used medically as Mandelic acid salt } \\
\text { for the treatment of urinary tract } \\
\text { infection (bacteriocidal) }\end{array}$ & $\begin{array}{c}\text { Jadhav et al., 2014; Joseph and } \\
\text { Priya, 2011; Golak-Siwulska et } \\
\text { al., } 2018\end{array}$ \\
\hline $\begin{array}{c}\text { Hexadecanoic acid, methyl } \\
\text { ester } \\
\text { (Methyl palmitate) }\end{array}$ & 97 & $10.22 \%$ & $\begin{array}{l}\text { Is the most common saturated fatty } \\
\text { acid in animals, plants and micro- } \\
\text { organisms with antioxidant and } \\
\text { antimicrobial activities }\end{array}$ & $\begin{array}{c}\text { Eman Mostafa and Farghaly, } \\
\text { 2014; Jadhav et al., 2014; } \\
\text { Joseph and Priya, 2011; Patel } \\
\text { et al., 2012; Golak-Siwulska et } \\
\text { al., } 2018\end{array}$ \\
\hline $\begin{array}{l}\text { 1, 6-Octadiene, } 3 \text {, } \\
\text { 7-dimethyl-, (S)- } \\
\text { (linalool) }\end{array}$ & 15 & $2.20 \%$ & Anti-stress & $\begin{array}{l}\text { Patel et al., 2012; Golak- } \\
\text { Siwulska et al., } 2018\end{array}$ \\
\hline $\begin{array}{l}\text { 9-Octadecenoic acid (Z)-, } \\
\text { methyl ester } \\
\text { (oleic acid) }\end{array}$ & 99 & $17.99 \%$ & $\begin{array}{c}\text { Mono-unsaturated fatty acid } \\
\text { associated with decreased LDL and } \\
\text { possibly increased HDL }\end{array}$ & $\begin{array}{l}\text { Fogarisa et al., 2018; Eman } \\
\text { Mostafa and Farghaly, 2014; } \\
\text { Jadhav et al., 2014; Golak- } \\
\text { Siwulska et al., } 2018\end{array}$ \\
\hline $\begin{array}{l}\text { 10,13-Octadecadienoic } \\
\text { acid, methyl ester }\end{array}$ & 99 & $4.25 \%$ & Unsaturated fatty acid & $\begin{array}{l}\text { Fogarisa et al., 2018; Golak- } \\
\text { Siwulska et al., } 2018 \\
\end{array}$ \\
\hline $\begin{array}{l}\text { Octadecanoic acid, methyl } \\
\text { ester }\end{array}$ & 98 & $10.18 \%$ & $\begin{array}{l}\text { Saturated fatty acid has antimicrobial } \\
\text { activity }\end{array}$ & $\begin{array}{c}\text { Fogarisa et al., 2018; Patel et } \\
\text { al., 2012; Golak-Siwulska et al., } \\
2018\end{array}$ \\
\hline
\end{tabular}

Anti-inflammatory,

Hypocholesterolemic, Cancer

preventive, Hepatoprotective, Alam et al., 2007; Jadhav et al.,

Nematicide, Insectifuge, $\quad$ 2014; Joseph and Priya, 2011;

9, 12-Octadecadienoic acid (Z,Z)- methyl ester (linoleic acid)

$99 \quad 30.10 \%$

Patel et al., 2012; Sarangi et

Antiacne, 5-Alpha reductase inhibitor al., 2006; Golak-Siwulska et al., Antiandrogenic, Antiarthritic,

Anticoronary, Insectifuge; It has Omega 6 fatty acid

Cell differentiation inducer: A method of treating a malignant tumor selected from the group consisting of leukemia,

Benzamide, 4-ethyl-Nmethallyl-

35

$2.36 \%$

colorectal cancer, ovarian cancer,

oral cancer, lung carcinoma, breast

carcinoma, prostate carcinoma, and melanoma

\begin{tabular}{cccc}
\hline $\begin{array}{c}\text { Methyl 20-methyl- } \\
\text { heneicosanoate }\end{array}$ & 95 & $1.94 \%$ & $\begin{array}{c}\text { Silicone elastomers in cosmetic esters } \\
\text { teeth impression molds }\end{array}$ \\
\hline $\begin{array}{c}\text { 1, 2-Benzenedicarboxylic } \\
\text { acid, diisooctyl ester }\end{array}$ & 64 & $2.90 \%$ & $\begin{array}{c}\text { Plasticizer compound: antimicrobial, } \\
\text { antifouling }\end{array}$
\end{tabular}

Joseph and Priya, 2011; Patel et al., 2012; Sarangi et al., 2006; Golak-Siwulska et al., 2018

Jadhav et al., 2014; GolakSiwulska et al., 2018

Jadhav et al., 2014; Eman Mostafa and Farghaly, 2014; Joseph and Priya, 2011; Patel et al., 2012 Golak-Siwulska et al., 2018; 
Table 3. Effects of housing types, sex and Oyster mushroom (Pleurotus ostreatus) extract levels on white blood cell count and white blood cell differential of rabbits

\begin{tabular}{cccccccccccc}
\hline & \multicolumn{1}{c}{ Housing types } & \multicolumn{3}{c}{ Sex } & \multicolumn{5}{c}{ Mushroom extract levels } \\
\hline Parameters & $\begin{array}{c}\text { Steel } \\
\text { hutch }\end{array}$ & $\begin{array}{c}\text { Wooden } \\
\text { hutch }\end{array}$ & SEM & Male & Female & SEM & $0 \mathrm{ml}$ & $5 \mathrm{ml}$ & $10 \mathrm{ml}$ & $15 \mathrm{ml}$ & SEM \\
\hline WBC $\left(\times 10^{9} / \mathrm{L}\right)$ & 7.69 & 7.29 & 0.42 & 7.30 & 7.65 & 0.40 & 6.90 & 7.48 & 7.41 & 8.13 & 0.57 \\
\hline Neutrophil $(\%)$ & 33.40 & 33.94 & 1.02 & 34.00 & 33.37 & 0.96 & $36.13^{\mathrm{a}}$ & $31.00^{\mathrm{b}}$ & $34.25^{\mathrm{ab}}$ & $33.38^{\mathrm{ab}}$ & 1.35 \\
\hline Lymphocyte (\%) & 65.07 & 64.35 & 0.95 & 64.31 & 65.06 & 0.89 & $62.75^{\mathrm{b}}$ & $67.25^{\mathrm{a}}$ & $64.00^{\mathrm{ab}}$ & $64.75^{\mathrm{ab}}$ & 1.26 \\
\hline Eosinophil (\%) & 0.40 & 0.29 & 0.13 & 0.50 & 0.19 & 0.12 & 0.13 & 0.38 & 0.38 & 0.50 & 0.17 \\
\hline Basophil (\%) & 0.33 & 0.47 & 0.21 & 0.25 & 0.56 & 0.19 & 0.50 & 0.25 & 0.25 & 0.63 & 0.28 \\
\hline Monocyte (\%) & 0.80 & 1.00 & 0.30 & 1.00 & 0.81 & 0.28 & 0.50 & 1.13 & 1.38 & 0.63 & 0.40 \\
\hline
\end{tabular}

a,b: Means in the same row with different superscripts differ significantly $(\mathrm{P}<0.05)$

$\mathrm{SEM}=$ Standard Error of Means

highest lymphocyte $(67.25 \%)$ from the white blood cell while the rabbits on $0 \mathrm{ml}$ (antibiotics and multivitamins) had the lowest $(62.75 \%)$. The study showed that rabbits kept under different housing types of steel hutch and wooden hutch, have similar white blood cell counts and white blood cell differential. Furthermore, the similar values of white blood cell counts and white blood cell differential of the rabbits housed in steel hutch and wooden hutch to the normal range of haematological value indices recommended for healthy rabbits as reported by Archetti et al. (2008) and Research Animal Resource (2009) indicates that housing rabbits in either steel hutch or wooden hutch would not affect negatively the body defense mechanism. The study revealed that sex did not influence the white blood cell and white blood cell differential of the rabbits. The result corroborates the report of Chineke et al. (2006) and Ozkan et al. (2012) who recorded non-significant difference of white blood cell of male and female rabbits. The study on the levels of administration of mushroom (Pleurotus ostreatus) extract in water revealed a significant effect on the white blood cell differential of the rabbits and this support Sogunle et al. (2016) who suggested that Oyster mushroom extract can replace antibiotics inclusion in drinking water of broiler chicken. The lower neutrophil value from rabbits on $5 \mathrm{ml}$ of Oyster mushroom (Pleurotus ostreatus) extract per litre of water as compared to the control and other mushroom extract levels implies that the immediate response mechanism of the rabbits in this group to protect against infection is the poorest (Harper et al., 1979; Ogbuewu, 2008). Furthermore, the higher lymphocyte values recorded from rabbits on Oyster mushroom (Pleurotus ostreatus) extract in drinking water may have been due to bacterial infections which would led to the production of more antibodies by the B lymphocytes to directly attack various infected cells. The lower percentage of lymphocyte from the rabbits on conventional antibiotics and multivitamins implies that the rabbits in this group are prone to be more susceptible to secondary and opportunistic infections (Ihedioha, 2008) while the higher values of the lymphocyte from rabbits on Oyster mushroom (Pleurotus ostreatus) extract indicates a more effective antibody production (Frandson, 2003). The study thus, indicates that administration of Oyster mushroom (Pleurotus ostreatus) extract as replacement for conventional multivitamins and antibiotics for rabbits can enhance the immediate response mechanism and production of antibodies to directly attack various infected cells mostly by bacterial infections and this confirm the reports of Morschhauser et al. (2000); Sandven (2000); Thomsen and Moland (2000); Stamets (2005); Nithya and Ragunathan (2009) and Akyuz et al. (2010) that Oyster mushroom possess antibiotic and immuneboosting properties that can fight against bacterial diseases and infection.

In Table 4, the interactive effects between housing types and sex on white blood cell count and white blood cell differential of rabbits are shown. Significant $(P<0.05)$ differences were obtained on eosinophil. The male rabbits housed in wooden hutch had the highest eosinophil $(0.75$ $\%$ ) from the white blood cell while the female rabbits housed in wooden hutch had the lowest $(0.00 \%)$. The result of white blood cell count and white blood cell differential in the interaction between housing types and sex revealed that the sex of the rabbit will not affect its body defense mechanism when housed in either steel hutch 
Table 4. Interactive effects between housing types and sex on white blood cell count and white blood cell differential of rabbits

\begin{tabular}{cccccc}
\hline & \multicolumn{2}{c}{ Steel hutch } & \multicolumn{2}{c}{ Wooden hutch } & SEM \\
\hline Parameters & Male & Female & Male & Female & \\
\hline WBC $\left(\times 10^{9} / \mathrm{L}\right)$ & 7.40 & 8.01 & 7.20 & 7.37 & 0.57 \\
\hline Neutrophil $(\%)$ & 32.13 & 34.86 & 35.88 & 32.22 & 1.35 \\
\hline Lymphocyte (\%) & 66.25 & 63.71 & 62.38 & 66.11 & 1.26 \\
\hline Eosinophil (\%) & $0.75^{\mathrm{a}}$ & $0.00^{\mathrm{b}}$ & $0.25^{\mathrm{ab}}$ & $0.33^{\mathrm{ab}}$ & 0.17 \\
\hline Basophil $(\%)$ & 0.00 & 0.71 & 0.50 & 0.44 & 0.28 \\
\hline Monocyte (\%) & 0.88 & 0.71 & 1.12 & 0.88 & 0.40 \\
\hline a,b: Means in the same row with different superscripts differ significantly $(\mathrm{P}<0.05)$ & &
\end{tabular}

a,b: Means in the same row with different superscripts differ significantly $(\mathrm{P}<0.05)$

SEM= Standard Error of Means WBC= White blood cell

Table 5. Effects of housing types, sex and Oyster mushroom (Pleurotus ostreatus) extract levels on serum biochemistry of rabbits

\begin{tabular}{|c|c|c|c|c|c|c|c|c|c|c|c|}
\hline \multirow[b]{2}{*}{ Parameters } & \multicolumn{2}{|c|}{ Housing types } & \multirow[b]{2}{*}{ SEM } & \multicolumn{2}{|c|}{ Sex } & \multicolumn{6}{|c|}{ Mushroom extract levels } \\
\hline & $\begin{array}{r}\text { Steel } \\
\text { hutch }\end{array}$ & $\begin{array}{l}\text { Wooden } \\
\text { hutch }\end{array}$ & & Male & Female & SEM & $0 \mathrm{ml}$ & $5 \mathrm{ml}$ & $10 \mathrm{ml}$ & $15 \mathrm{ml}$ & SEM \\
\hline Protein $(\mathrm{g} / \mathrm{dl})$ & 6.82 & 7.23 & 0.27 & 7.00 & 7.04 & 0.27 & 7.04 & 7.29 & 6.75 & 7.01 & 0.38 \\
\hline Albumin (g/dl) & 3.56 & 3.83 & 0.14 & 3.76 & 3.63 & 0.14 & 3.68 & 3.95 & 3.60 & 3.55 & 0.20 \\
\hline Globulin (g/dl) & 3.26 & 3.40 & 0.16 & 3.24 & 3.41 & 0.16 & 3.36 & 3.34 & 3.15 & 3.46 & 0.23 \\
\hline Cholesterol (mg/dl) & 58.44 & 59.69 & 1.57 & 58.88 & 59.25 & 1.57 & 62.50 & 58.50 & 56.75 & 58.50 & 2.23 \\
\hline $\begin{array}{l}\text { Triglycerides (mg/ } \\
\mathrm{dl} \text { ) }\end{array}$ & 66.94 & 63.13 & 1.67 & 65.94 & 64.13 & 1.67 & 65.00 & 68.00 & 61.88 & 65.25 & 2.36 \\
\hline HDL (mg/dl) & 31.16 & 31.04 & 1.22 & 31.11 & 31.09 & 1.22 & 33.30 & 30.29 & 29.38 & 31.44 & 1.73 \\
\hline LDL (mg/dl) & $13.89^{\mathrm{b}}$ & $16.02^{\mathrm{a}}$ & 0.75 & 14.58 & 15.34 & 0.75 & 16.20 & 14.61 & 15.00 & 14.01 & 1.06 \\
\hline Creatinine (mg/dl) & 1.34 & 1.07 & 0.36 & 1.39 & 1.01 & 0.36 & 1.94 & 1.00 & 1.03 & 0.85 & 0.51 \\
\hline Urea (mg/dl) & 10.34 & 10.24 & 0.52 & 10.58 & 10.01 & 0.52 & 9.29 & 10.96 & 10.39 & 10.54 & 0.73 \\
\hline Glucose (mg/dl) & 105.44 & 111.56 & 4.13 & 108.31 & 108.69 & 4.13 & 109.63 & 111.63 & 104.88 & 107.88 & 5.84 \\
\hline
\end{tabular}

or wooden hutch. However, the difference in eosinophil values from the rabbits housed in steel hutch with the females having no presence of eosinophil in the white blood cell might imply that male rabbits have a higher chance of getting sick when housed in steel hutch and this supports the report of Robert et al. (2003) who suggested that absence of eosinophil in rabbit's white blood cell is an indication that the rabbits had not suffered from any allergic reaction and parasitic infection.

The effects of housing types, sex and varying levels of Oyster mushroom extract on serum biochemistry of rabbits are presented on Table 5 . There was significant $(\mathrm{P}<0.05)$ effect of housing types on low density lipoproteins. The rabbits housed in wooden hutch had higher low density lipoproteins $(16.02 \mathrm{mg} / \mathrm{dl})$ than the rabbits housed in steel hutch $(13.89 \mathrm{mg} / \mathrm{dl})$. However, sex and the varying levels of Oyster mushroom did not significantly $(\mathrm{P}>0.05)$ influence the serum biochemistry of the rabbits. The study on serum biochemistry of rabbits kept in steel hutch and wooden hutch revealed housing types only affected low density lipoprotein in the serum of the rabbits and this support Salama et al. (2015) who reported no significant effect due to housing model on all studied biochemical parameters. The lower value of the low density lipoprotein (LDL) in the serum of the rabbits housed in steel hutch indicates lesser amount of non-beneficial cholesterol in the blood serum as compared to rabbits housed in wooden hutch and the higher LDL in rabbits kept in wooden hutch might be due to stress from single housing with no visual or physical contact with other rabbits (Dontas et al., 2011). This support Serra et al. (2004) and Weiss et al. (2004) which stated that stress of isolation of rabbits is a potent stressor. The sex of the rabbits did not influence the serum biochemistry, affirming Yamada et al. (2004) who reported no statistically 
significant difference for serum glucose levels of male and female rabbits; Szabo and Milisits, 2007; Mahesh et al.. (2008) who observed no sex related difference in serum creatinine levels and no indication for sex differences in nitrogen metabolism, growth and muscle mass. The study on the levels of administration of Oyster mushroom (Pleurotus ostreatus) extract in water revealed non-significant difference on the blood serum biochemistry of the rabbits and this implies that Oyster mushroom (Pleurotus ostreatus) extract can be used as substitute for conventional multivitamins and antibiotics in drinking water without any deleterious effect on the blood serum profile. This result support the findings of Alam et al. (2011) who reported no adverse effects on total protein, creatinine, blood urea nitogen, uric acid, glucose from the serum of rats fed a diet containing a $5 \%$ powder of Pleurotus ostreatus fruiting bodies.

\section{Conclusion}

It was concluded that housing rabbits in wooden hutch and replacement of conventional antibiotics and multivitamins with oyster mushroom (Pleurotus ostreatus) extract as phytobiotic for rabbits would optimize their health status.

\section{References}

1. Akyuz M, Onganer AN, Erecevit P and Kirbag (2010) Antimicrobial activity of some edible mushrooms in the eastern and southeast Anatolia region of Turkey. Gazi Journal of Science, 23(2): 125-130.

2. Alam N, Amin R, Khan A, Ara I, Shim MJ, Lee MW and Lee TS (2008). Nutritional Analysis of Cultivated Mushrooms in Bangladesh; Pleurotus ostreatus, Pleurotus sajor-caju, Pleurotus florida and Calocybe indica. Mycobiology, 36(4): 228-232.

3. Alam N, Hossain S, Khair A, Amin R, Asaduzzaman K (2007). Comparative effects of Oyster mushrooms on plasma lipid profile of hypercholesterolaemic rats. Bangladesh Journal of Mushroom, 1: 15-22.

4. Alam N, Yoon KN, Lee TS and Lee UY (2011). Hypolipidemic activities of dietary Pleurotus ostreatus in Hypercholesterolemic rats. Mycobiology, 39(1): 45-51.

5. Archetti I, Tittarelli C, Cerioli M, Brivio R, Grilli G, Lavazza A (2008). Serum chemistry and hematology values in commercial rabbits: Preliminary data from Industrial farms in Northern Italy. $9^{\text {th }}$ World Rabbit Congress, June 10-13, 2008 - Verona - Italy. 1147-1152.

6. Chang ST and Buswell JA (1996). Mushroom nutriceuticals World Journal of Microbiology and Biotechnology, 12: 473476.
7. Chineke CA, Ologun AG and Ikeobi CON (2006). Haematological parameters in rabbit breeds and crosses in humid tropics. Pakistan Journal of Biological Sciences, 9(11): 2102-2106.

8. Elmastas M, Isildak O, Turkekul I and Temur N (2007). Determination of antioxidant activity and antioxidant compounds in wild edible mushrooms. Journal of Food Composition and Analysis, 20: 337-345.

9. Eman Mostafa M and Farghaly FA (2014). Bioactive compounds of fresh and dried Pleurotus ostreatus mushroom. International Journal of Biotechnology for Wellness Industries, 3: 4-14.

10. Fogarasi M, Socaci SA, Dulf FV, Diaconeasa ZM, Farcas AC, Tofana M and Semeniuc CA (2018). Bioactive compounds and volatile profiles of five Transylvavian wild edible mushrooms. Molecules, 23: 3272-3286.

11. Frandson RD (2003). Anatomy and Physiology of Farms Animals, 31: 462.

12. Golak-Siwulska I, Kaluzewicz A, Spizewski T, Siwulski M and Sobieralski K (2018). Bioactive compounds and medicinal properties of oyster mushrooms (Pleurotus sp.). Folia Horticulturae, 30(2): 191-201.

13. Gugolek A, Kowalska D, Konstantynowicz M, Strychalski J and Bukowska B (2011). Performance indicators, health status and coccidial infection rates in rabbits fed diets supplemented with white mustard meal. Annals of Animal Science, 11(3): 425-432.

14. Harper HA, Rodwell VW and Mayes PA (1979). Review of Physiological Chemistry ( $17^{\text {th }}$ Edition). Librairie du Liban.

15. Hoy ST (2008). Guidelines for minimum standards on rabbit housing in Germany. $9^{\text {th }}$ World Rabbit CongressJune 10-13, 2008 - Verona - Italy.

16. Hoy ST and Verga M (2006). Welfare indicators. In: Maertens, L., Coudert, P. (Editions); Recent Advances in Rabbit Sciences, ILVO, Melle, Belgium, 71-74.

17. Ihedioha JT, Okerie-Kanu CO and Iwuogu UM (2008). Leukocyte Alterations associated with continual subacute blood loss. Proceedings of 33rd Annual Conference of Nigerian Society for Animal Production, Ogun, 55-57.

18. Jadhav V, Kalase V and Patil P (2014). GC-MS analysis of bioactive compounds in methanolic extract of Holigarna grahamii (wight) Kurz. International Journal of Herbal Medicine, 2(4): 35-39

19. Jain NC (1986). Schalm Veterinary Haematology (4 ${ }^{\text {th }}$ edition). Lea and Febiger, Philadelphia. 285.

20. Joseph B and Priya RM (2011). Bioactive compounds from endophytes and their potential in pharmaceutical effect: A Review. American Journal of Biochemistry and Molecular Biology, 1: 291-309.

21. Kaneko JJ (1989). Clinical Biochemistry of Domestic Animals ( $4^{\text {th }}$ edition). Academic Press, New York, California. USA. Pp. 898.

22. Khan A, Amin R, Uddin N, Tania M and Alam N (2008). Comparative study of the nutritional composition of Oyster mushrooms cultivated in Bangladesh. Bangladesh Journal of Mushroom, 2(1): 9-14.

23. Lebas F, Coudert P, De Rochambeau H and Thebault RG (1997). The Rabbit: Husbandary, Health and Production. 
Food and Agriculture Organisation, Animal Production and Health Division: Rome, Italy. ISBN-92-103441-9.

24. Mahesh B, Boyd Y, Robson D, Pillai R, Ratnatunga C and Pigott D (2008). Does furosemide prevent renal dysfunction in high-risk cardiac surgical patients? Results of double-binded prospective randomised trial. European Journal of Cardiothoraciac Surgery, 33: 370-376.

25. Mailafia SL, Onakpa MM and Owoleke OE (2010). Problems and prospects of rabbit production in Nigeria: a review. Bayero Journal of Pure and Applied Sciences, 3(2): 20-25.

26. Morschhäuser J, Köhler G, Ziebuhr W, Blum-Oehler G, Dobrindt U and Hacker J (2000). Evolution of microbial pathogens. Philosophical Transactions of the Royal Society of London; Biological Sciences, 355: 695-704.

27. Minitab ${ }^{\circledR}$ 17.1.0 (2013). Minitab 17.1.0 Statistical Software. State College, Pennsylvania: Minitab, Incorporation. Retrieved from www.minitab.com.

28. Nithya R and Ragunathan R (2009). Synthesis of silver nanoparticle using Pleurotus Sajor-caju and its antimicrobial study. Digest Journal of Nanomaterials and Biostructures, 4(4): 623-629.

29. Ogbuewu IP (2008). Physiological responses of rabbits fed graded levels of Neem (Azadirachta indica) leaf meal. M. Agric. Tech Thesis submitted to the Department of Animal Reproductive Physiology, Federal University of Technology, Owerri.

30. Ozkan C, Kaya A and Akgul Y (2012). Normal values of haematological and some biochemical parameters in serum and urine of New Zealand White rabbits. World Rabbit Science, 20: 253-259.

31. Patel Y, Naraian R and Singh VK (2012). Medicinal properties of Pleurotus species (Oyster mushroom): a review. World Journal of Fungal and Plant Biology, 3(1): 1-12.

32. Randox (2012). Clinical Chemistry Analysers. Randox Laboratories Linited. Randox.com. Research Animal Resource (RAR), 2009. Reference values for laboratory animals: Normal haematological values. Research Animal Resource, University of Minnesota. Retrieved from $h t t p: / /$ www.ahc.umn.edu/rar/refvalues.html.

33. Robert K, Murray D, Daryl K, Grammer K and Rodwell W (2003). Harper Biochemistry, 29th Edition.

34. Roeschlau P, Berut E and Gruber JW (1974). Clinical Chemistry, 12: 403.

35. Salama MS, Morsy WA, Mohamed RA, Eltholth MM and El-Midany SA (2015). Effect of weaning age and housing model on feed intake, growth performance, hematobiochemical parameters and economic efficiency of post weaning New Zealand White rabbits. Alexandria Journal of Veterinary Sciences, 46: 48-56.

36. Sandven P (2000). Epidemiology of canidemia. Revista Iberoamericana de Micologia, 17: 73-81.
37. Sarangi I, Ghosh D, Bhutia SK, Mallick SK and Maiti TK (2006). Anti-tumor and immunomodulating effects of Pleurotus ostreatus mycelia-derived proteoglycans. International Immunopharmacology, 6(8): 1287-1297.

38. Serra M, Pisu MG, Floris I, Floris S, Cannas E, Mossa A, Trapani G, Latrofa A, Purdy RH and Biggio G (2003). Social isolation increases the response of peripheral benzodiazepine receptors in the rat. Neurochemistry International, 45:141-148.

39. Shaeffer R and Kime LF (2008). Agricultural Alternatives; Rabbit Production. Agricultural Research and Cooperative Extension Publication, College of Agricultural Sciences, Pennsylvania State University. www.cas.psu.edu

40. Shamtsyan M, Konusova V, Maksimova Y, Goloshchev A, Panchenko A, Simbirtsev A, Petrishchev N and Denisovad $\mathrm{N}$ (2007. Immunomodulating and anti-tumor action of extracts of several mushrooms. Journal of Biotechnology, 113: 77-83.

41. Sogunle OM, Adesunboye AA, Kolawole AT, Odutayo OJ and Safiyu KK (2016). Growth performance and immune status of broiler chickens on oral administration of Oyster mushroom extract. Book of Abstract of the $1^{\text {st }}$ World Congress on Innovations for Livestock Development, pp. 47. Held at Sentrim Elementaita Lodge, Nakuru, Kenya, $26^{\text {th }}$ $30^{\text {th }}$ June, 2016. Available online at: www.ilinova.org.

42. Stamets P (2005). Mycelium Running. Berkeley, California: Ten Speed Press.

43. Szabo,A. and Milisits G (2007). Clinicochemical followup of broiler rearing a five-week study. Acta Veterinaria Hungarica, 55: 451-462.

44. Thomson KS and Moland ES (2000). The new blactamases of Gram-negative bacteria at the dawn of the new millennium. Microbes and Infection, 2: 1225-1235.

45. Wang HX and Ng TB (2000). Quinqueginsin, a novel protein with anti-human immunodeficiency virus, antifungal, ribonuclease and cell-free translationinhibitory activities from American ginseng roots. Biochemical and Biophysical Research Communications, 269: 155-159.

46. Wasser SP and Weis AL (1999). Medicinal properties of substances occurring in higher Basidiomycetes mushrooms: Current perspectives (Review). International Journal of Medicinal Mushooms, 1: 31-62.

47. Weiss IC, Pryce CR, Jongen-Rêlo AL, Nanz-Bahr NI and Feldon J (2004). Effect of social isolation on stressrelated behavioural and neuroendocrine state in the rat. Behavioural Brain Research, 152: 279-295.

48. Wolff ER, Wisbeck SE, Silveira MLL, Gern RMM, Pinho MSL and Furlan SA (2008). Antimicrobial and antineoplastic activity of Pleurotus ostreatus. Applied Biochemistry and Biotechnology, 151: 402-412.

49. Yamada S, Ito T, Tamura T and Shiomi M (2004). Agerelated changes in serum/plasma biochemical parameters of WHHLMI rabbits. Experimental Animals Tokyo, 53: 159163. 


\section{MANUSCRIPT SUBMISSION GUIDELINE}

\section{TYPES OF PAPERS}

Research Article: describe new and confirmed findings including experimental procedures. This type of paper should contain: Abstract, Keywords, Abbreviations, Introduction, Materials and Methods, Results and Discussions, Conclusion, Acknowledgements, References. The tables and figures should be inserted in the text. A typical Research Article contains 8-10 manuscript pages (including tables and figures).

Short Communication: describe experimental procedures and report for a completed work, but not preliminary findings. It must contain the Abstract, Keywords, Abbreviations, the core of the paper including tables and/or figures, Acknowledgements, References. It must not exceed 2 pages.

Review: an invited paper which gives an overview of a topical field of interest for a wide spectrum of readers and includes Abstract, Keywords, Abbreviations, topical sections and subsections and References. The manuscript may include $15-20$ pages and at least 50 relevant references.

\section{PROCESSING OF PAPERS}

All submitted articles are peer-reviewed, by a blind-review refereeing process. Each manuscript is subjected first to a preliminary examination by the journal editor to establish if it fits the scope of the Journal. In a positive case, the manuscript is reviewed by two or three independent referees with expertise in the field which matches the manuscript title and content. The reviewers' recommendations determine whether an article will be: accepted (A), accepted with minor changes (Am), accepted with major revisions and significant changes (AM) or rejected (R). The manuscript can be accepted either without revision after the reviewing (A) or after revision (Am or AM).

On the basis of the reviewers critical remarks, the Editor and Editor-in-Chief decides to return the manuscript to the author within two (2) weeks for major or minor revision with specified reviewer's critical remarks or to reject it. For articles which require revisions, the same reviewers may be used to ensure that the corrections and improvements were processed and quality of the revised article is acceptable.

The correspondence with authors is done by the Publication office and the series' editor, confirming the receipt of the manuscript by the Editorial Office, the outcome of the reviewing, and the acceptation or the rejection of the manuscript are communicated to the author. All the communication between the Editorial Office and the author is realized via e-mail.

The Editor in Chief reserves the right to refuse any article, and to make suggestions and/ or modifications before publication. The proofs of the manuscript are sent to the author in PDF format. After checking and correcting they should be returned within 48 hours. Finally, the article (PDF format) matching the printed version is sent to the author. The publishers shall not be held responsible for errors which are the result of authors' oversights.

Page Charges Since this journal does not receive direct funding or support from any governmental or external agency or sponsors, the authors are required to pay a processing fee for each article accepted for publication. These charges cover some of the costs for the journal's production, online availability, hosting and archiving and allows a greater circulation for the journal as well as immediate online availability (open access) for unlimited data download worldwide.

\section{SUBMISSION PROCESS}

The first author and/or corresponding author should follow the checklist before submitting the article, namely to respect the writing and formatting requirements outlined in the Instructions for authors (mentioned also in the Journal homepage, http://journals.usamvcluj.ro/ index.php)

The instructions for authors include information about preparing a manuscript for submission to the journal of interest and the online submission process. Microsoft Word (2003) formats of Manuscript should be submitted in electronic form, on line to the Editorial Office of the preferred journal series: Agriculture/ Horticulture/ Animal Science and Biotechnology/ 
Veterinary Medicine/ Food Science and Technology. For Articles with multiple authors, we would expect a "corresponding author" to be responsible for the article during the refereeing process after submission.

\section{INSTRUCTIONS FOR AUTHORS}

The manuscript (review, research article, or short communication) should be clearly written on A4 size paper/portrait ( $21 \times 29,7 \mathrm{~cm})$, in a concise, grammatically correct UK English spelling.

For a more efficient editing process of the volume, please observe the following instructions:

- page setup: all margins $2.5 \mathrm{~cm}$;

- section headings of the paper will include the following: Introduction, Materials and Methods, Results and Discussion, Conclusions and References;

- the full text paper will be edited in Times New Roman (TNR) 12;

- the title of the paper will be typed in TNR 14, bold, left aligned;

- below the title, the last name and first name of the author(s) will be followed by authors' affiliation. All will be left aligned.

- the paper will begin with an abstract in English of no more than 2600 characters, written with TNR 11 ;

- below the abstract, up to 5 keywords (simple or composite) should be typed in TNR 11;

- text spacing will be as follows:

- top of page to title, 1 line

- title to authors' name, 1 line

- authors' name to authors' affiliation, 1 line

- authors' affiliation to abstract, 1 line

- abstract to keywords, 1 line

- keywords to text, 1 line

- one line spacing before subheadings and section heading, no space after heading and subheading

Article Title (max.145 characters): Times New Roman (TNR) 14, Title case (This means only using capital letters for the principal words. Articles, conjunctions, and prepositions do not get capital letters unless they start the title.) Bold, Left aligned

Authors' names: TNR 12, normal, Left aligned, TNR - CAPITAL LETTERS for SURNAME.

Authors' academic degrees should not be included.
Authors' affiliation and addresses: TNR 11, left aligned. Includes: Institution, full address - postal code, city, country. The corresponding author indicates the email address.

\section{Abstract}

Max. 2600 characters, TNR 11, informative and self-explanatory and should be written in past tense, which summarize concisely the purpose, methods and important results without excessive methodical and experimental details. Standard nomenclature should be used and abbreviations should be avoided.

Keywords: 3 - 5 key words, in alphabetical order, TNR 11.

The article text: font TNR 12 , justified

The entire manuscript should be typed single spaced, with margins of $2.5 \mathrm{~cm}$. No page numbers are required. Indent new paragraphs at $1.5 \mathrm{~cm}$.

The style of heading and subheadings should be as follows:

The first heading should be left aligned, 1 line spacing, with UPPERCASE LETTERS.

The first sub-heading should be left justified, bold and Title case.

Sub-sub-headings should be left justified, bold, italics.

\section{Introduction (TNR 12, BOLD)}

Should give a concise background and provide the rationale to the presented study. It should provide a clear statement of the problem and should be understandable by a broad range of scientists.

\section{Materials and Methods \\ (TNR 12, BOLD)}

Should give detailed and sufficient information of materials and procedures to allow experiments to be reproduced. Previously published procedures and sources of laboratory procedures should be cited. Information on the equipment model, manufacturer's name and address including the city and country should be provided. The procedures should be written in the past tense.

\section{Results and Discussion}

(TNR 12, BOLD)

The results will include tables, figures, graphs, statistical analyses and sample calculations inserted in the text. The discussion should comment the meaning of the findings and a direct interpretation 
to draw conclusions. It can outline working hypotheses, theories, and applications.

Tables should be inserted in the text and numbered consecutively with Arabic numerals with selfexplanatory, descriptive titles and supplied with a heading and a legend. Text in tables should be TNR 10. Only horizontal lines should be used within a table. Column headings should be brief, with units of measurement in parentheses, TNR 10.

The titles of the table should be placed above the tables, written in TNR11, left aligned. All abbreviations should be defined in footnotes. Use superscript letters (not numbers) for footnotes and keep footnotes to a minimum.

Table 1. An example of a table

\begin{tabular}{ccccc}
\hline $\begin{array}{c}\text { Col- } \\
\text { umn head- } \\
\text { ing }\end{array}$ & $\begin{array}{r}\text { Col- } \\
\text { umn }(t)\end{array}$ & $\begin{array}{r}\text { Col- } \\
\text { umn B }(t)\end{array}$ & $\begin{array}{r}\text { Col- } \\
\text { umn A }(t)\end{array}$ & $\begin{array}{r}\text { Col- } \\
\text { umn B }(t)\end{array}$ \\
\hline Line 1 & 1 & 2 & 1 & 2 \\
\hline Line2 & 3 & 4 & 3 & 4 \\
\hline Line 3 & 5 & 6 & 5 & 6 \\
\hline
\end{tabular}

All figures should be numbered with Arabic numerals. Every figure should have a caption. All photographs, schemas, graphs and diagrams are to be referred to as figures. Line drawings should be good quality scans. Figures must be embedded into the text. Preferred format of figures are PNG, JPEG, GIF. Lettering and symbols should be clearly defined either in the caption or in a legend provided as part of the figure. Figures should be placed as close as possible to the first reference to them in the paper.

Please ensure that all the figures are of 300 DPI resolution as this will facilitate good output.

The figure number and title should be typed bellow the figure in TNR 11, left justified. It must include sufficient description so that the figure is understandable without reading the text. If two images fit next to each other, these may be placed next to each other to save space.
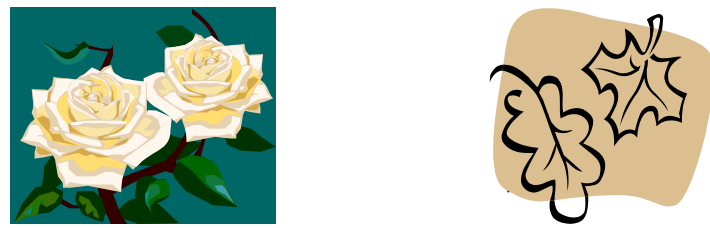

Figure 1. (a) first picture; (b) second picture
All mathematical equations/ formulae should be embedded in the text. Mathematical and physical formulas should be presented in the MS Word formula editor. Equations should be placed on a separate line from the text with a blank space above and below. Equations should be clear and expressions used should be explained in the text. The equations should be numbered consecutively at the outer right margin, as shown in Eq.(1). The number should be written in TNR 10 pt in parenthesis.

$$
\rho=\frac{m}{V}
$$

$$
\text { Where: } \begin{aligned}
& \rho-\text { density } \\
& \mathrm{m}-\text { mass } \\
& \mathrm{V}-\text { volume }
\end{aligned}
$$

Please use IS (International System of Units) system for the definition of the units.

\section{Conclusion (TNR 12, BOLD)}

State only conclusions that are directly supported by the evidence and the implications of the findings in one paragraph.

Acknowledgements. It is an optional section that may contain acknowledgements of personal and/or financial assistance.

Authors are responsible for obtaining written permission to use any copyrighted text and/or illustration.

\section{References (TNR 12, BOLD)}

Citations of the references in the text: author's surname followed by the year of publication (ex: Smith, 2011) or for 2 authors, surnames and year (Smith and Johnson, 2010) or for more than two authors, surname followed by et al. (ex: Britton et al., 2009).

The citations in the text can be also made as follows: Perry (2003) proved that ...

This is in agreement with the results obtained by several authors (Brown, 1999; Kramer, 2004; Smith, 2008).

If a cited author had two or more papers published during the same year, the reference, both in the text and in the reference list, should be identified by a lower case letter like ' $a$ ' and ' $b$ ' after the date to distinguish the works, e.g. Jackson, 2001 a,b. 
The tables and figures are cited in the text in parentheses (ex: Tab. 1. or Fig. 1.) and must be inserted in the text after their citation.

List of References (should be listed TNR 11, at the end of the paper in alphabetical order, justify aligned. Citations of articles "in preparation", "in press" or "manuscript submitted" are not allowed. Each reference includes the author(s) surname and name(s), the year of publication (in parenthesis), the article title, journal name, volume and page numbers. All authors should be mentioned in the reference list, as shown below.

\section{Examples of references to be listed correctly:}

Books

Abbot MC (1997). Introduction in Molecular Cell Biology. $4^{\text {th }}$ ed. Academic Press, San Diego, $75 \mathrm{p}$.

\section{Book Chapter}

Bolder AG (1995). Apples, p. 3-37. In: Janick J, Moore JN (Eds.). Advances in fruit breeding. California Univ. Press, West Lafayette, Indiana.

\section{Periodical}

Clitherow G, Duffield B, Clarck J (1991). Managing plant diseases through milk: an innovative approach. J Amer Soc Hort Sci 96:645-648.

\section{Journal Articles}

Chun OK (2005). Daily consumption of phenolics and total antioxidant capacity from fruit and vegetables in the American diet. J Sci Food Agric 85(2):1715-1724.

Hertog MGL, Hollman PCH, Katan MB (1992). Content of potentially anticarcinogenic flavonoids in different vegetables and fruits commonly consumed in the Netherlands. J Agric Food Chem 40:2379-2383.

Harker FR, Marsh KB, Young H, Murray SH, Gunson FA, Walker SB (2002). Sensory interpretation of instrumental measurements: sweet and acid taste of apple fruit. Postharvest Biol Technol 24:241-250.

\section{Conference Proceedings' Papers}

Randell CJ, Morris DA, Tayler PL (2000). Advances in watermelon fertility. Proc Trop Reg Amer Soc Hort Sci 14:223-231.

\section{Reports}

Germany. Department of Agriculture (1999). Agricultural statistics for 1998. Germany Dept. Agr., München.

\section{PhD Dissertations}

Trueman JD (2001). Optimization of tissue culture techniques and Agrobacterium mediated transformation in wheat. Colo. State Univ., Fort Collins, PhD Diss. Abstr. 81-247.

\section{Regulations}

European Commission, (2011), Proposal for a Regulation of the European Parliament and of the Council on Support for Rural Development by the European Agricultural Fund for Rural Development (EAFRD), Brussels: 1-143.

Council Regulation 1782, (2003), Regulation establishing common rules for direct support schemes under the common agricultural policy and establishing certain support schemes for farmers and amending Regulations (EEC) No 2019/93, (EC) No 1452/2001, (EC) No1453/2001, (EC) No 1454/2001, (EC) 1868/94, (EC) No 1251/1999, (EC) No1254/1999, (EC) No 1673/2000, (EEC) No 2358/71 and (EC) No 2529/2001. Official Journal of the European Union 46 (L 270): 1-69.

Electronic Journal Articles and Electronic

Books should be cited as standard journal articles and books except add an availability statement and date of accession following the page(s). Available at: www.usfw.gov/ozarkstreams. Accessed 2004 Nov. 29.

For journal names cited in the reference list, use the standard abbreviations of the journals, e.g. Bulletin UASVM Agriculture, 75(1)/2018

The standard abbreviations of journal names are found in the "List of Serial Title Word Abbreviations", published by the ISSN International Centre.

Nomenclatures, Unit, and Abbreviations. Nomenclatures for chemicals and biochemical, microorganisms and genes should follow the guidelines in the instructions to authors of international journals, e.g. SI units (System International Unites) should be used whenever possible. Abbreviations should be used as recommended by IUPA-IUB Commission on Biochemical Nomenclature and Related Documents.

In addition to abbreviation to SI unit, other common abbreviations may be used without definition in Table (the same abbreviations are used for plural forms): hour(s) $=\mathrm{h}$, minute(s) $=$ min, $\operatorname{second}(\mathrm{s})=\mathrm{sec}, \operatorname{liter}(\mathrm{s})=\mathrm{L}, \operatorname{mililiter}(\mathrm{s})=$ $\mathrm{mL}$, $\operatorname{meter}(\mathrm{s})=\mathrm{m}$, centimeter $(\mathrm{s})=\mathrm{cm}, \operatorname{gram}(\mathrm{s})$ $=\mathrm{g}, \operatorname{miligram}(\mathrm{s})=\mathrm{mg}, \operatorname{microliter}(\mathrm{s})=\mu \mathrm{L}$, micrometer(s) $=\mu \mathrm{m}, \operatorname{micron}(\mathrm{s})=\mu \mathrm{m}$, standard deviation $=\mathrm{SD}$, standard error $=\mathrm{SE}$, molar $=\mathrm{M}$, mole $=$ mol. 


\section{PUBLICATION ETHICS STATEMENT}

The journal Bulletin of University of Agricultural Sciences and Veterinary Medicine Cluj-Napoca is committed to the local and international academic community. In order to assure the highest standards for published articles a double blind reviewing policy is applied. In pursue of the compliance with academic standards, all parties involved in the publishing process (the authors, the editors and the editorial board and the reviewers) agree to meet the responsibilities stated below in accordance to the Journal publication ethics and malpractice statement.

\section{DUTIES OF AUTHORS:}

- the author(s) warrant that the submitted article is an original work, which has not been previously published, and that they have obtained an agreement from any co-author(s) prior to the manuscript's submission.

- the authors should not submit articles describing essentially the same research to more than one journal.

- the authors(s) make certain that the manuscript meets the terms of the Manuscript submission guideline regarding appropriate academic citation and that no copyright infringement occurs.

- the authors(s) should inform the editors about any conflict of interests and report any errors they subsequently discover in their manuscript.

\section{DUTIES OF EDITORS AND THE EDITORIAL BOARD:}

- the editors, together with the editorial board, are responsible for deciding upon the publication or rejection of the submitted manuscripts based only on their originality, significance and relevance to the domains of the journal.

- the editors evaluate the manuscripts compliance with academic criteria, the domains of the journal and the guidelines.

- the editors must at all times respect the confidentiality of any information pertaining to the submitted manuscripts.

- the editors assign the review of each manuscript to two reviewers chosen according to their domains of expertise. The editors must take into account any conflict of interest reported by the authors and the reviewers.

- the editors must ensure that the comments and recommendations of the reviewers are sent to the author(s) in due time and that the manuscripts are returned to the editors, who take the final decision to publish them or not.

\section{DUTIES OF REVIEWERS:}

- the reviewers must objectively evaluate the manuscripts based only on their originality, significance and relevance to the domains of the journal.

- the reviewers must in due time supply clear, objective and relevant comments and recommendations meant to improve the content of the submitted manuscript.

- the reviewers must at all times respect the confidentiality of any information pertaining to the submitted manuscripts.

- reviewers should not review manuscripts in which they have conflicts of interest resulting from competitive, collaborative, or other relationships or connections with any of the authors, companies, or institutions connected to the papers.

Ethical Guidelines for Authors. Any submitted article should not have been previously published or currently be under consideration for publication elsewhere.

Author Statement Form. At the submission of each paper, the corresponding author, on behalf of the authors, signs an "Author Statement Form" to declare and confirm that the paper submitted for publication in Bulletin of University of Agricultural Sciences and Veterinary Medicine (BUASVM) Cluj-Napoca (the series should be mentioned: Agriculture/ Horticulture/ Animal Science and Biotechnologies/ Veterinary Medicine/ Food Science and Technology) is an original one, not published and not submitted to another publication elsewhere. The corresponding author also declares that all the co-authors have contributed to the work, are responsible for the validity and originality of data contained therein and have all agreed to submit the current version, allowing the editors, in case of paper acceptance, to make 
editorial changes (grammar, punctuation, spelling and format corrections), but no major alterations of the paper.

Screening for plagiarism. The authors of all articles published in the five series of Bulletin of University of Agricultural Sciences and Veterinary Medicine Cluj-Napoca must be aware and understand that the editorial board of the journal prevents and sanctions attempts and acts of plagiarism.

Plagiarism represents a violation of the basic principles of ethics and cannot be tolerated. Examples of plagiarism include: "word-forword" copying of portions of another's writing without enclosing the copied passage in quotation marks and acknowledging the source in the appropriate scholarly convention (1), the use of a particularly unique term or concept that one has come across in reading without acknowledging the author or source (2), the paraphrasing or abbreviated restatement of someone else's ideas without acknowledging this text (3), or the copying of text portions from one's own publications (self-plagiarism) (4). Avoid false citation, a text attributed to a cited source, from which it was not obtained.

All of the editors of the five series of Bulletin of University of Agricultural Sciences and Veterinary Medicine Cluj-Napoca are using "Plagiarism Detector", a dedicated software program for screening submissions, to ensure the originality of articles by detecting published and web-searchable manuscripts. Therefore, authors are announced that discovered plagiarism leads to the rejection of the manuscript submitted for publication and to the definitive elimination of the author as a future possible contributor of the journal, as well as to an official notification to the author's institution. 